\title{
HUMAN CAPITAL LOSS IN CORPORATE BANKRUPTCY
}

\author{
by
}

John R. Graham*

Duke University and NBER

\author{
Hyunseob Kim \\ Cornell University
}

Si Li

Wilfrid Laurier University

\author{
Jiaping Qiu \\ McMaster University
}

\begin{abstract}
CES 13-37
July, 2013

The research program of the Center for Economic Studies (CES) produces a wide range of economic analyses to improve the statistical programs of the U.S. Census Bureau. Many of these analyses take the form of CES research papers. The papers have not undergone the review accorded Census Bureau publications and no endorsement should be inferred. Any opinions and conclusions expressed herein are those of the author(s) and do not necessarily represent the views of the U.S. Census Bureau. All results have been reviewed to ensure that no confidential information is disclosed. Republication in whole or part must be cleared with the authors.

To obtain information about the series, see www.census.gov/ces or contact Fariha Kamal, Editor, Discussion Papers, U.S. Census Bureau, Center for Economic Studies 2K132B, 4600 Silver Hill Road, Washington, DC 20233, CES.Papers.List@census.gov.
\end{abstract}

\section{Abstract}




\begin{abstract}
This paper quantifies the "human costs of bankruptcy" by estimating employee wage losses induced by the bankruptcy filing of employers using employee-employer matched data from the U.S. Census Bureau's LEHD program. We find that employee wages begin to deteriorate one year prior to bankruptcy. One year after bankruptcy, the magnitude of the decline in annual wages is 30\% of pre-bankruptcy wages. The decrease in wages persists (at least) for five years post-bankruptcy. The present value of wage losses summed up to five years after bankruptcy amounts to $29-49 \%$ of the average pre-bankruptcy market value of firm. Furthermore, we find that the ex-ante wage premium to compensate for the ex-post wage loss due to bankruptcy can be of similar magnitude with that of the tax benefits of debt.
\end{abstract}

Keyword: Bankruptcy; Costs of financial distress; Human capital; Wage loss; Capital structure

JEL Classification: G3, G32, G33, J24, J31, J33;

\footnotetext{
* John Graham (john.graham@duke.edu), Fuqua School of Business, Duke University, Durham NC 27708, phone: (919) 660-7857, fax: (919) 660-8038; Hyunseob Kim (hyunseob.kim@cornell.edu), Samuel Curtis Johnson Graduate School of Management, Cornell University, Ithaca, NY 14583, phone: (607) 255-8335; Si Li (sli@wlu.ca), School of Business and Economics, Wilfrid Laurier University, Waterloo, Ontario N2L 3C5, Canada, phone: (519) 884-0710 ext. 2395, fax: (519)888-1015; Jiaping Qiu (qiu@mcmaster.ca), DeGroote School of Business, McMaster University, Hamilton, Ontario L8S 4M4, Canada, phone: (905) 525-9140 ext. 23963, fax: (905) 521-8995. We thank Bert Grider at the Triangle Census Research Data Center for help with data and clearance requests. We also thank Andrew Karolyi, Roni Michaely, and seminar participants at Cornell University and the 2012 RDC Conference at Chicago for helpful feedback. Any opinions and conclusions expressed herein are those of the author and do not necessarily represent the views of the U.S. Census Bureau. All results have been reviewed to ensure that no confidential information is disclosed. This research uses data from the Census Bureau's Longitudinal Employer Household Dynamics Program, which was partially supported by the following National Science Foundation Grants SES-9978093, SES-0339191 and ITR-0427889; National Institute on Aging Grant AG018854; and grants from the Alfred P. Sloan Foundation. We are grateful to Lynn LoPucki of UCLA for sharing his Bankruptcy Research Database. Kim acknowledges generous financial support from the Kwanjeong Educational Foundation. Li and Qiu acknowledge financial support from the Social Sciences and Humanities Research Council of Canada.
} 


\section{Introduction}

In the corporate bankruptcy literature, the magnitude of financial distress and bankruptcy costs is an important empirical question (e.g., Senbet and Wang, 2012). In particular, indirect costs, such as the loss of product market shares, inefficient asset sales (Shleifer and Vishny, 1992), and losses for non-financial stakeholders including suppliers and employees (Titman, 1984), are argued to be critical. ${ }^{2}$ These indirect costs, however, are difficult to quantify particularly for a broad sample of firms. A few papers provide evidence on specific indirect costs of financial distress, including the loss of product market shares (Opler and Titman, 1994) and asset fire sales (Pulvino, 1998, 1999; Ramey and Shapiro, 2001). However, despite the importance of human capital in firms and in the overall economy, not much attention has been paid in examining the labor consequences of corporate bankruptcy and financial distress. ${ }^{3}$

In this study, we seek to fill this void by quantifying the magnitude of the "human costs of bankruptcy," or more generally, the consequences of financial distress and bankruptcy for employees. Using employee-employer matched data from the U.S. Census Bureau's Longitudinal Employer-Household Dynamics (LEHD) program, we are able to observe individual workers' employers and wages across time (as well as other worker characteristics). Combining the worker-level information from LEHD with a comprehensive database of Chapter 11 bankruptcy cases, we quantify the wage loss that employees experience around the bankruptcy filing of their employers. Using 138 bankruptcy filings by public firms from 1992

\footnotetext{
${ }^{1}$ The bankruptcy literature also examines the institutional nature of Chapter 11 (Ayotte and Morrison, 2009; Bharath, Panchapegesan, and Werner, 2010), post-bankruptcy firm performance (Hotchkis, 1995), and managerial incentives in financial distress (Goyal and Wang, 2012).

${ }^{2}$ In contrast, the literature shows that direct costs of financial distress, such as litigation fees, are relatively small ranging from $1 \%$ to $6 \%$ of pre-bankruptcy firm value (Warner, 1977; Altman, 1984). In addition, Andrade and Kaplan (1998) use a sample of 31 highly levered transactions and show that the total costs of financial distress (which include both direct and indirect costs) range from $10 \%$ to $23 \%$ of pre-distress firm value.

${ }^{3}$ For example, wages account for roughly two-thirds of national output in the U.S. economy (Source: Bureau of Economic Analysis).
} 
to 2008 and information on 96,538 workers employed by the bankrupt firms across the U.S., we find that employee wages begin to deteriorate one year prior to bankruptcy. Furthermore, for the average worker the decline in annual wages is roughly $30 \%$ of pre-bankruptcy wages. The average present value of wage losses from the year of bankruptcy to five years after bankruptcy amounts to almost $30 \%$ of the market value of assets measured one year prior to bankruptcy. In addition, we find that almost half of the employees of the bankrupt firm leave the firm within five years after a bankruptcy filing.

Existing theories provide several potential reasons that employees may experience wage losses following bankruptcy beyond unemployment spells. First, investment in firm- or industry-specific human capital (Becker, 1962; Neal, 1995) or good matches between employees and employers (Jovanovic, 1979) may be lost after a job loss (Topel, 1991). Second, employees may have received a premium over their market prevailing wages (or marginal value of product) in their previous employers due to the effects of unions (Robinson, 1989) or employee entrenchment (Harris and Holmstrom, 1982). Alternatively (but not exclusively), employers may have paid wage premiums to induce workers to exert unobservable efforts (Lazear, 1981). Hence, when employees lose their jobs due to bankruptcy, they are likely to earn less if their subsequent jobs pay market wages. ${ }^{4}$

Our findings have important implications for at least three strands of literature. First, our paper adds to the empirical literature on corporate bankruptcy in financial economics and law. Previous research has examined the effects of bankruptcy filings on firm-level outcomes such as accounting performance, asset size, and management turnover (Hotchkiss, 1995; LoPucki and Whitford, 1992; Gilson, 1989). But relatively less attention has been paid to the

\footnotetext{
${ }^{4}$ For employees who stay with the bankrupt firm post-bankruptcy, the mechanisms for wage losses may be different (e.g., wage bargaining with distressed employers). We separately examine wage changes for workers who keep being employed by the bankrupt firm and those who leave the firm in Section 3.3.
} 
consequences of bankruptcy for employees, partly due to limitations in data on workers. To the best of our knowledge, our paper is the first to use worker-level micro data and to quantify human capital loss experienced by workers after bankruptcy filings of employers. ${ }^{5}$ Moreover, given the active debate in law and finance as to the efficacy of Chapter 11 as a means to reorganize businesses and to protect employees, the results in our paper would improve our understanding of the beneficiaries of the Chapter 11 bankruptcy process. $^{6}$

Second, by providing estimates of costs of financial distress for labor, our paper contributes to the capital structure literature. The trade-off theory of capital structure posits that the primary benefit and cost of debt financing are tax deductibility of interest expense and the so-called costs of financial distress (e.g., Kraus and Litzenberger, 1973). At least beginning with Miller (1977), one central debate has been whether distress costs are large enough to offset the tax benefits of debt. Existing capital structure research suggests that the expected total costs of financial distress may not be large enough to offset the tax benefits of debt (see e.g., Andrade and Kaplan (1998) and Graham (2000)). ${ }^{7}$ Given the large magnitude of wage loss estimates we find in corporate bankruptcy (for the average employee, about 1.4 times of pre-bankruptcy annual wages are lost in present value terms), the indirect cost of financial

\footnotetext{
${ }^{5}$ Eckbo, Thornburn, and Wang (2012) estimate earnings losses due to bankruptcy for corporate executives, and Benmelech, Bergman, and Enriquez (2012) use firm and pension plan-level wage data to estimate the magnitude of downward wage renegotiation in financial distress of airline firms. However, neither of these papers uses individual worker-level data to estimate worker wage losses across a broad sample of financially distressed firms.

${ }^{6}$ The 1978 Bankruptcy Reform Act, which formed the basis of the modern bankruptcy code, suggests that preserving jobs is an important goal of Chapter 11 (see Ondersma (2009) and references therein). For example, House of Representative Report, No. 95-595, p. 220 (1977) states "The purpose of a business reorganization case, unlike a liquidation case, is to ... provide its employees with jobs ... It is more economically efficient to reorganize than to liquidate, because it preserves jobs and assets."

${ }^{7}$ In particular, Andrade and Kaplan (1998) state that "the expected costs of financial distress for most public companies are modest if not negligible because the probability of financial distress is very low for most public firms." In addition, Graham (2000) finds that even extreme estimates of distress costs may not justify observed debt choices of the average firms, and thus concludes that firms, on average, appear to use debt conservatively. Note that both Andrade and Kaplan (1998) and Graham (2000) reach their conclusions using the expected costs of distress based on the historical probability of distress. Recently, Almeida and Philippon (2007) show that using risk-adjusted probability of distress, the expected, risk-adjusted costs of distress could be of the same order of magnitude with the tax benefits of debt.
} 
distress can potentially explain the conservative debt usage by U.S. public firms (Graham, 2000). ${ }^{8}$

Furthermore, the results in our paper provide an important underpinning for theories arguing that the risk of losing human capital due to financial distress and bankruptcy is a key driver of corporate leverage choices. Models of Titman (1984), Jaggia and Thakor (1994), and Berk, Stanton, and Zechner (2010) show that this concern for labor should be a consideration for ex-ante employer capital structure choices (and Agrawal and Matsa (2012) and Kim (2012) find consistent evidence). Our paper contributes to this literature by showing that employees suffer significant wage losses due to financial distress, and bankruptcy in particular, which is a key presumption of the theories.

Lastly, our paper contributes to the labor economics literature that examines displaced employees' wage loss (e.g., Jacobson, LaLonde, and Sullivan, 1993; Couch and Placzek, 2010). The results in our paper advance the literature by showing that both workers who stay with or leave the employer post-bankruptcy experience substantial earnings losses, suggesting that employer financial distress has negative effects on its employees beyond job displacements.

To gauge the effects of potential human capital loss on employer capital structure, we estimate an ex-ante cost of financial distress to the firm (which is what matters for capital structure choices) based on our estimates of ex-post loss of human capital. In particular, for differing levels of leverage, we calculate additional wage costs which would compensate employees for different risks of financial distress (i.e., compensating wage differentials). To the extent that workers can anticipate their potential wage loss due to financial distress and

\footnotetext{
${ }^{8}$ Note that we distinguish the ex-post wage loss borne by employees from the ex-ante cost imposed on the firm due to the potential wage loss. Employees may demand higher wages on highly levered firms because working in such firms increases the employees' unemployment risk and incurs larger expected wage losses. In Section 3.4, we translate the ex-post personal loss of workers' human capital into an ex-ante cost of financial distress from the firm's perspective, thereby linking the ex-ante cost to employer leverage decisions.
} 
require additional compensation before the actual bankruptcy occurs, this approach is likely to provide reasonable estimates for the ex-ante indirect cost of distress related to human capital loss. ${ }^{9}$

We find that for the average BBB-rated firm, the expected cost of additional compensation for bankruptcy-driven human capital loss can be as large as $8 \%$ of firm value, which is of similar magnitude with tax benefits of debt for the firm. Moreover, across firms with different levels of credit ratings and leverage, the magnitude of the ex-ante wage premium due to "human capital risk" is of similar magnitude with that of the tax benefit of debt. Therefore, our results suggest that taking human costs of bankruptcy into account can potentially resolve the "debt conservatism puzzle."10

The rest of the paper proceeds as follows. The next section describes the data, variables, and summary statistics. Results, implications, and robustness tests are given in Section 3. Section 4 further discusses our results. The last section concludes.

\section{Data and Summary Statistics}

\subsection{Sample Selection}

\footnotetext{
${ }^{9}$ As mentioned in Agrawal and Matsa (2012), workers' demand for higher wages in firms with increased financial distress risk does not require that workers directly observe firms' leverages. The impact of leverage on job security is likely to be conveyed in informative signals from coworkers, management, the media, and from other aspects of the economic environment. Brown and Matsa (2012) find that job seekers accurately perceive firms' financial health, suggesting that firm employees likely perceive the effect of financial health on their job security as well (or even more accurately). The evidence that compensating wage differentials respond to unemployment risk further supports this argument (Abowd and Ashenfelter, 1981; Topel, 1984; Li, 1986; Hamermesh and Wolfe, 1990; Chemmanur et al., 2012).

${ }^{10}$ Of course, using compensating wage differentials may not be the only approach to translate the ex-post wage loss for employees into ex-ante cost of debt for the firm. For example, employees of a highly-leveraged firm might optimally choose to invest less in their firm-specific human capital, which reduces their productivity (Jaggia and Thakor, 1994). Highly levered firms may also lose high-quality employees or job candidates to competing firms with lower leverage due to low job stability (Brown and Matsa, 2012). The bottom line is that as long as employees anticipate the effects of the firm's financial health on the stability of their jobs, the firm would ultimately bear the costs associated with potential wage loss. Nonetheless, our approach based on compensating differentials provides a straight-forward, yet sensible way to quantify the cost of debt to the firm.
} 
We begin by identifying corporate bankruptcy cases based on the UCLA-LoPucki Bankruptcy Research Database (BRD).${ }^{11}$ This database has been used in the literature to study corporate bankruptcy (e.g., Jiang et al., 2012; Wang, 2009). The BRD contains public companies with more than $\$ 100$ million of assets (measured in 1980 dollars) that filed cases under Chapter 11 of the U.S. Bankruptcy Code from October 1, 1979 to present. ${ }^{12}$ We exclude financial and utilities firms based on their SIC codes.

For these Chapter 11 filers, we obtain worker-level information such as age, education, gender, and wages from the U.S. Census Bureau's Longitudinal Employer-Household Dynamics (LEHD) program, and firm-level information from the Compustat and CRSP databases. The LEHD program covers 30 participating U.S. states as of $2012^{13}$ and provides detailed information on individual workers' wage and other characteristics. We link datasets from LEHD with other Census Bureau business data, and subsequently with Compustat and CRSP using the Business Register Bridge (BRB). Specifically, among the databases available from LEHD, we use the Individual Characteristics File (ICF) which provides worker-level characteristic variables such as gender and birth year, the Employment History File (EHF) which contains annual and quarterly earnings for each worker-firm pair, and the Unit-toWorker Imputation File (U2W) which is used for job-location imputation at the SIC (or NAICS) industry and county level. Then we use the Compustat-SSEL Bridge (CSB) in conjunction with the SSEL-Name and Address File (SSEL-NA) to link components of LEHD with Compustat.

\footnotetext{
${ }^{11}$ We thank Lynn M. LoPucki at UCLA for sharing this database.

12 The sample period starts after 1979 to ensure that sample firms fall under the 1978 Bankruptcy Reform Act, which marked a substantial change to U.S. bankruptcy law. 1978 Bankruptcy Reform Act established the current system of federal bankruptcy courts and the regime of Chapter 11 reorganization, and became effective on October 1, 1979.

13 See p. 15 of the following document for the list of states covered by LEHD as of August 2008: http://lehd.did.census.gov/led/library/tech_user_guides/overview_master_zero_obs_103008.pdf.
} 
We restrict our sample to workers for whom we have information on age, education, and gender, which serve as controls in our wage regressions. To avoid complications associated with early retirement and legal ages for employment, we exclude workers who are older than 55 or younger than 22 in the year before a bankruptcy filing. Furthermore, we focus on "long-tenure" workers (i.e., workers with six or more years of tenure with the bankrupt firm one year before its Chapter 11 filing) who presumably have accumulated significant (specific) human capital at the time of bankruptcy filing (Jacobson, LaLonde, and Sullivan, 1993).

In addition to the LEHD datasets, we use the Longitudinal Business Database (LBD) to collect additional information on total wages and the number of employees at the firm level. The LBD tracks more than five million establishments every year, essentially covering the entire U.S. economy. The variables available in the database include the number of employees, annual payroll, industry classifications, geographical location (at the county or zip code level), and parent firm identifiers. Given that the LEHD program provides employment data only for 30 participating states, the LBD is useful to obtain more comprehensive data on employment at bankruptcy firms.

\subsection{Summary Statistics}

Table 1 presents summary statistics on bankrupt firms. These statistics are based on data from their latest fiscal year before bankruptcy. Panel A shows that during the sample period from 1992 to 2008, 138 out of 412 (33\%) bankrupt events from the Bankruptcy Research Database (BRD) with Compustat information have matched workers from LEHD. ${ }^{14}$ Perhaps not surprisingly, 70\% (99 out of 138) of the firms are clustered during the technology

\footnotetext{
${ }^{14}$ The LEHD program covers the period from 1990 to 2008. Since we require pre-bankruptcy information on wages, bankruptcy events in the final sample begin from 1992.
} 
bubble and the recession afterward (1998-2003) (Panel B). And 43\% of the 138 cases are in the manufacturing sector (Panel C).

In Panel D of Table 1, we examine whether the sample of bankrupt firms matched with LEHD is representative of the full sample of bankrupt firms from the BRD by comparing the characteristics of the two groups. The panel shows that the bankrupt firms matched with LEHD are on average larger than the full sample of bankruptcy firms from the BRD in terms of sales, book and market assets, market equity, and the number of employees. ${ }^{15}$ Both groups of firms are highly leveraged with about $65 \%$ mean book leverage one year before a bankruptcy filing, and have similar mean market-to-book ratios at around 1.1. The average return on assets of the matched sample is $5 \%$, which is higher than that of the full bankruptcy sample $(2 \%)$. In addition, compared to the full sample of bankrupt firms in the BRD, the bankrupt firms matched to LEHD have higher labor intensity and pay a lower wage per worker.

[Table 1 about here]

Table 1, Panel E shows the dynamics of firm characteristics beginning from five years to one year before a bankruptcy filing. Over the five year period before bankruptcy, leverage ratios increase from $40 \%$ to $65 \%$, and return on assets (ROA) declines from 0.14 to 0.04 . The market-to-book ratio also declines from 1.54 to 1.05 . Similarly, other variables such as market value of equity, the number of employees, and the average wage per worker experience marginal declines over the period. These trends indicate that an increase in financial leverage and a significant deterioration in profitability and firm value before Chapter 11 filings.

Table 2 presents summary statistics on employees of the bankrupt firms at one year prior to bankruptcy filings using information from LEHD during the 1992-2008 period. Following the literature (e.g., von Wachter, Song, and Manchester, 2009; Couch and Placzek,

\footnotetext{
${ }^{15}$ The Census Bureau does not permit disclosing median values.
} 
2010; von Wachter and Davis, 2012) we construct a control sample of employees who are i) employed by non-bankrupt firms and ii) not displaced from an employer. Due to computational constraints, we only use randomly selected $1 \%$ workers from the LEHD universe who satisfy the criteria as a control group. We impose the same requirements for industry (i.e., excluding financial and utilities sectors), tenure, and age on the control group as for the workers in the sample of bankrupt firms.

The table shows that employees in the bankrupt firms have similar levels of education (14 years, indicating that average workers have some college education) with those in the control group. In addition, workers in the bankruptcy and control groups have similar age and work experiences (43 vs. 42 and 23 vs. 22). However, the average wage (in 2001 constant dollars) of the employees of bankrupt firms is about $\$ 5,000$ less than that for the control group of workers. Finally, the table shows that only $55 \%$ of employees stay with the bankrupt firms five years after bankruptcy, indicating that a significant fraction of workers leave the firm postbankruptcy (Hotchkiss, 1995).

[Table 2 about here]

\section{Empirical Results}

\subsection{Wage Trends before and after Bankruptcy}

In this section, we analyze univariate changes in wages of workers employed by bankrupt firms. Table 3 presents the evolution of average wages for all employees in the bankrupt firms matched with LEHD at each point in time from five years before to five years after bankruptcy. The average wage declines over the years starting from $t-3$, with the sharpest decline at year $t$. In year $t$, the average wage declines by $21 \%$ relative to the benchmark level in 
year $\mathrm{t}-5$. The decline in wages is persistent: Up until year $\mathrm{t}+5$, the cumulative decrease in the average employee wage relative to t-5 reaches $32 \%$ of the pre-bankruptcy wages.

[Table 3 about here]

\subsection{Difference-in-Difference Estimates of Wage Loss in Bankruptcy}

One limitation of the univariate analysis in the previous section is that factors other than bankruptcy events, such as macroeconomic and industry conditions, or unobserved heterogeneity across workers may drive the changes in wages after bankruptcy. For example, employees of bankrupt firms may have low abilities and thus experience declines in wages. To deal with concerns of this sort, we perform multivariate regression analysis of wage loss using a difference-in-difference framework. Specifically, we estimate the following regression equation:

$$
y_{i t}=\alpha_{i}+\gamma_{t}+x_{i t} \beta+\sum_{k=-m}^{m} D_{i t}^{k} \delta_{k}+\varepsilon_{i t}
$$

where $\mathrm{i}$ indicates workers and $\mathrm{t}$ indicates years, and $y_{i t}$ is worker $\mathrm{i}$ 's log real wage in year $\mathrm{t}$. $\alpha_{i}$ and $\gamma_{t}$ denote worker and time fixed effects, respectively. $x_{i t}$ includes observable worker characteristics, and $D_{i t}^{k}$ is a dummy variable equal to one if year $\mathrm{t}$ is $\mathrm{k}$ years after (or before if $\mathrm{k}$ $<0)$ bankruptcy and zero otherwise $(-4 \leq \mathrm{k} \leq 5)$. $\varepsilon_{i t}$ is the error term.

In Table 4 Column (1), we include workers who were employed by bankrupt firms in the sample one year prior to a bankruptcy filing (but do not include a control group of workers). Column (1) thus shows results of a fixed-effect regression that includes worker and year fixed effects. The control variables $x_{i t}$ include the following employee characteristics: years of experience, years of education $\times$ years of experience, and years of experience $\times$ gender. We do 
not include education and gender individually because they are absorbed by the worker fixed effects, and age because it is collinear with work experience and education.

[Table 4 about here]

In Columns (2) and (3) of Table 4, we introduce a control group of workers (1\% randomly sampled workers from the LEHD universe) and pool them with employees of bankrupt firms (i.e., treatment group). In addition to the controls in Column (2), Column (3) further includes two-digit SIC industry fixed effects to control for different wage levels across industries. We then perform a difference-in-difference regression using the comparison group to estimate the earnings changes that would have occurred in the absence of bankruptcy (i.e., counterfactual earnings), controlling for worker and year fixed effects and individual characteristics. The estimates of $\delta_{k}$ capture the change in employee wages of bankrupt companies during each year relative to control firms, and thus are our main interest. Specifically, we estimate the following equation:

$$
y_{i t}=\alpha_{i}+\gamma_{t}+x_{i t} \beta+\sum_{k=-m}^{m} \text { Bankruptcy }_{i} \times D_{i t}^{k} \delta_{k}+\varepsilon_{i t},
$$

where Bankruptcy B $_{i}$ an indicator variable equal to one if worker $\mathrm{i}$ was an employee of a bankrupt firm and zero if the worker is in the control group. The definitions of other variables are the same as in those in Equation (1).

Table 4 reports the estimates of $\delta_{k}$. The regression results show that there is an increase in wages up till two years prior to bankruptcy. The regressions further show that employee wages start to decline significantly from year $\mathrm{t}-1$ and the lower wages persist several years after bankruptcy (all the indicator variables for years $t$ to $t+5$ are significantly negative at a conventional level in columns 2 and 3). This result suggests that after controlling for year and individual worker fixed effects and observable worker characteristics, there is a significant 
labor income loss (about 30\% compared with the pre-bankruptcy income level) for employees of the bankrupt firms, relative to those of the non-bankrupt firms. ${ }^{16}$ The magnitude of this income loss is consistent with that of the estimate obtained in the univariate analysis in Table 3.

Figure 1 visually presents the cumulative wage change based on the estimates in Table 4, Column 3. The figure shows that the wage of employees of bankrupt firms increases slightly till year $\mathrm{t}-3$ and then starts to deteriorate in year $\mathrm{t}-1$ (the year before bankruptcy filing). For each year from year $t+1$ to $t+5$, the employees lose about one third of the benchmark wage (the average wage across $t-6$ and $t-5)$.

[Figure 1 about here]

\subsection{Cross Sectional Variation in Wage Loss}

Our main analysis shows a significant decline in wages for employees in bankrupt firms. In this section, we investigate potential reasons that those workers experience significant earnings losses after bankruptcy filings of their employers. Particularly, in Table 5 Column (1), we examine whether the magnitudes of wage losses are different between the employees who stay with the bankrupt firm and those who leave the firm. We employ an indicator variable which is equal to one if the worker leaves the bankrupt firm within five years post-bankruptcy and zero otherwise. We then interact the dummy variable with the event time indicators for t-4 to $\mathrm{t}+5$ in our regression.

\footnotetext{
${ }^{16}$ We use the coefficient estimates on the indicator variables from $t-1$ to $t+5$ in Table 4 to obtain the magnitude of income loss. For example, the coefficient on the t-1 indicator variable in Column (3) is -0.082 , which is the difference between $\log$ (wage in $\mathrm{t}-1)$ and $\log$ (benchmark wage). This means that the wage in $\mathrm{t}-1$ divided by the benchmark wage is equal to $\exp (-0.082)=0.92$, which implies an $8 \%$ decline of wage in $\mathrm{t}-1$ relative to the benchmark wage. We perform the same calculation using the coefficients on the indicator variables from $t$ to $t+5$, and then obtain an average annual wage loss of $28 \%$ relative to the benchmark wage. The average annual loss is $24 \%$ and $36 \%$ respectively if we use the estimates from Column (1) and Column (2).
} 
Column (1) shows that the coefficients on the event time indicators exhibit generally smaller magnitude compared to those in the main regression models in Table 5, indicating that the employees who stay with the bankrupt firms experience a smaller (yet significant) wage loss during the post-bankruptcy period than the average worker of the bankrupt firms. The coefficients on the interaction terms between the dummy variable and the time indicators are negative and significant from year $\mathrm{t}$ through $\mathrm{t}+4$, suggesting that the employees who ultimately leave the bankrupt firms experience a significantly larger wage loss than those who remain in the firms. For example, four years after the bankruptcy filing, workers who leave the firm lose $47 \%$ of their annual wages, while those who stay with the firm lose only $22 \%$ of their annual wages. This result suggests that loss of firm-specific human capital (which is presumably lost once workers leave a firm) accounts for part of the wage losses.

\section{[Table 5 about here]}

In Table 5 Column (2), we define a dummy variable equals to one if the worker leaves the industry that he or she has been working in at the bankrupt firm, and zero otherwise. The result shows that both groups of workers experience significant wage losses. Perhaps not surprisingly, the workers who switch their industry after bankruptcy see a larger wage cut than those who stay within the previous industry, suggesting that a loss of industry-specific human capital drives part of the wage loss (Neal, 1995).

Next, we examine whether the magnitude of wage losses varies depending on the extent to which workers are covered by labor unions. We obtain industry-level data on union coverage from Hirsch and Macpherson (2003) who collect the information from the Current Population Survey Outgoing Rotation Group Earnings Files. Then, we define a dummy variable equals to one if the worker is employed in an industry having an above-median level of union coverage, and zero otherwise. The results in Table 5 Column (3) show that wage 
losses are larger for employees in industries with higher unionization rates. One plausible explanation for this result is that employees in highly unionized industries are paid wage premium above the market wage before bankruptcy due to union rent. Then, these workers might have experienced a larger wage loss post-bankruptcy by moving to a less unionized employer or by downward renegotiating of their wages during financial distress.

\subsection{Wage Loss and Capital Structure}

In this section, we use our regression estimates in Table 4, Column (3) to provide a back-of-the-envelope estimate of the present value of wage losses (relative to firm value). Panel E of Table 1 shows that the average real wage per worker for bankrupt firms in t- 5 is $\$ 37,876$. Based on the regression coefficients in Table 4 Column (3) and assuming a 5\% real discount rate, the present value of wage losses per worker from $t$ to $t+5$ is equal to $\$ 51,021 .{ }^{17}$ In addition, the number of employees at t-5 is 15,728 for an average bankrupt firm. Hence, the total present value of wage loss for an average firm is $\$ 802.46$ million $(=\$ 51,021 \times 15,728)$. Given that the average market value of assets for sample firms is about $\$ 2,754$ million in t-1 ( $\$ 1,652$ million in $t-5)$, the present value of wage losses for years $t$ to $t+5$ as a ratio of firm value ranges from $29 \%$ (if using market assets in $\mathrm{t}-1$ ) to $49 \%$ (if using market assets in $\mathrm{t}-5$ ), suggesting a significant employee wage loss due to bankruptcy relative to firm value.

[Table 6 about here]

The estimates in Table 6 give us an idea of the magnitude of "ex post human costs of bankruptcy." An employee who works for a firm with a larger ex post wage loss due to bankruptcy would require a wage premium ex ante, or else the employee will work for a firm that has a lower ex post wage loss, all else equal. In order to examine the implication of the $e x$

\footnotetext{
${ }^{17}$ See Table 6 for a detailed procedure to compute the present value of wage loss per worker.
} 
post wage loss estimates for a firm's ex ante capital structure choice, we need to translate these numbers into an ex ante wage cost for firms induced by their use of leverage.

To convert the ex post wage loss into the ex ante wage premium, we follow an approach similar to that in Almeida and Philippon (2007) and derive the present value of wage loss, using a simple valuation tree and the risk-adjusted default probability. We provide the details of the approach in Appendix B. The basic idea is that considering future bankruptcy costs (i.e., wage losses), an employee would demand the same risk-adjusted present value of expected wages from two companies with different bankruptcy probabilities (but everything else are the same). Our result is intuitive: the additional ex-ante wage premium is equal to the increase in the present value of the expected wage loss due to bankruptcy.

Table 7 provides the estimation results of wage premiums by credit ratings, based on a simple two-period model and an infinite-horizon model. The estimates in the two-period model consider only one year of ex-post wage loss, while those in the infinite horizon model consider all future ex-post wage losses. These estimates can be thought of as the lower and the upper bounds of the wage premium due to potential bankruptcy, respectively.

An accurate estimation of the wage premium requires information on the expected tenure of employees in potential bankrupt firms. A recent report by the Bureau of Labor Statistics shows that the median number of years that workers had been with their current employer is 4.6 in January $2012 .{ }^{18}$ Note, however, that the expected tenure of workers is likely longer than the realized tenure of current employees given their expected future employment in the current firm. Thus, we examine the robustness of our estimation by computing the wage premiums assuming periods of five and ten years as well. For each of the credit rating groups, we calculate the wage premium as a percentage of the market value of assets, and then

\footnotetext{
${ }^{18}$ See http://www.bls.gov/news.release/pdf/tenure.pdf.
} 
compare the premiums with the estimates of tax benefit of debt provided by Almeida and Philippon (2007) and Molina (2005). Table 7 shows that the magnitude of the ex-ante wage premium is of similar magnitude to that of the marginal tax benefit of debt across credit ratings under the assumed expected tenure of five years or larger.

[Table 7 about here]

The estimates in Table 7 need to be interpreted with a few caveats in mind. First, our estimates of wage loss are based on the average ex-post wage loss across all bankrupt firms in our sample. The magnitude of wage losses due to bankruptcy could differ across different companies and across different ratings. For instance, it is possible that a wage loss is larger for low rating firms than for high rating firms, and thus the estimates of the ex-ante wage cost based on the full sample may under-estimate the cost for firms with low ratings. Second, we use the (risk-adjusted) probability of default in estimating the wage costs for the sample of the firms that actually filed for Chapter 11 (i.e., bankruptcy). It is possible that default probability is larger than the probability of bankruptcy filings and thus our estimates may be biased upward.

\section{Discussions}

The results in this paper should be interpreted with the following caveats in mind. First, high leverage could lead to financial distress, but not necessarily bankruptcy. For example, firms in financial distress could resolve distress through out-of-court private workout. In this paper, we estimate the human capital loss resulting from bankruptcy (i.e., Chapter 11) filings. Because firms that file for Chapter 11 could experience more severe financial distress than 
firms that choose a private workout, our estimates for worker wage losses may be biased upwardly.

Second, our study does not distinguish whether bankruptcy is caused by financial distress (e.g., the firm's financial positions deteriorate due to high debt burden even if its underlying operations remain strong) or by economic distress. Our sample firms have an average leverage ratio as high as $65 \%$ one year prior to bankruptcy (see Table 1), suggesting that the firms may be in financial distress. At the same time, the average ROA (whose nominator is EBITDA) is 5\%, lower than the average ROA for Compustat firms (about 10\%). These statistics indicate that bankrupt firms in our sample may experience both financial and operational distress.

Third, it is possible that firms that file for bankrupt ex post are those that have low exante costs of financial distress. That is, these firms may have chosen highly levered capital structure exactly because they expected lower costs of financial distress. To the extent that firms "self-select" to bankruptcy in this manner, our estimates of wage losses may understate the costs of financial distress for the entire universe of firms.

\section{Conclusion}

This study quantifies the human costs of bankruptcy. We find that employee wages start to deteriorate prior to bankruptcy and the decline in wages persists at least for five years after bankruptcy. The magnitude of the decline in annual wages one year after a bankruptcy filing is about $30 \%$ of pre-bankruptcy wages. In addition, using the estimated human costs of bankruptcy, we provide an estimate of total wage losses relative to firm value. We then convert the ex-post wage loss into an ex-ante wage premium from the perspective of the firm. We find 
that for the average firm, the ex-ante wage premium is of similar magnitude to that of the tax benefits of debt. The analysis in this paper thus suggests that the cost of debt associated with employee wage losses in financial distress could potentially explain the conservative debt usage by U.S. corporations. 


\section{References}

Abowd, John M., and Orley C. Ashenfelter, 1981, Anticipated Unemployment, Temporary Layoffs, and Compensating Wage Differentials, NBER Chapters, in: Studies in Labor Markets, pages 141-186 National Bureau of Economic Research, Inc.

Agrawal, Ashwini K., and David A. Matsa, 2012, Labor Unemployment Risk and Corporate Financing Decisions, Journal of Financial Economics Forthcoming.

Almeida, Heitor, and Thomas Philippon, 2007, The Risk-Adjusted Cost of Financial Distress, Journal of Finance, 62-6, 2557-86

Altman, Edward I., 1984, A Further Empirical Investigation of the Bankruptcy Cost Question, Journal of Finance, 39-4, 1067-89

Andrade, Gregor, and Steven N. Kaplan, 1998, How Costly is Financial (not Economic) Distress? Evidence from Highly Levered Transactions that Became Distressed, Journal of Finance, 53-5, 1443-93.

Ayotte, Kenneth M., and Edward R. Morrison, 2009, Creditor Control and Conflict in Chapter 11, Journal of Legal Analysis, 1-2, 511-51.

Becker, Gary S., 1962, Investment in Human Capital: A Theoretical Analysis, Journal of Political Economy, 70-5, 9-49.

Benmelech, Efraim, Nittai K. Bergman, and Ricardo J. Enriquez, 2012, Negotiating with Labor under Financial Distress, Review of Corporate Finance Studies Forthcoming.

Berk, Jonathan, Richard Stanton, and Josef Zechner, 2010, Human Capital, Bankruptcy, and Capital Structure, Journal of Finance, 65-3, 891-926.

Bharath, Sreedhar, Venky Panchapegesan, and Ingrid Werner, 2010, The Changing Nature of Chapter 11, Working paper, Arizona State University.

Brown, Jennifer and David Matsa, 2012, Boarding a Sinking Ship? An Investigation of Job Applications to Distressed Firms, Working Paper, Northwestern University.

Chemmanur, Thomas J., Yingmei Cheng, and Tianming Zhang, 2012, Human Capital, Capital Structure, and Employee Pay: An Empirical Analysis, Journal of Financial Economics, forthcoming.

Couch, Kenneth A., and Dana W. Placzek, 2010, Earnings Losses of Displaced Workers Revisited, American Economic Review, 100-1, 572-589.

Davis, Steven J., and Till von Wachter, 2012, Recessions and the Costs of Job Loss, Brookings Papers on Economic Activity, forthcoming.

Eckbo, B. Espen, Karin S. Thorburn, and Wei Wang, 2012, How Costly is Corporate Bankruptcy for Top Executives?, Working Paper, Tuck School of Business at Dartmouth. 
Gilson, Stuart, 1989, Management Turnover and Financial Distress, Journal of Financial Economics, $25,241-262$.

Goyal, Vidhan K., and Wei Wang, 2012, Provision of Incentives in Chapter 11 Firms, Working Paper, Hong Kong University of Science and Technology.

Graham, John R., 2000, How Big are the Tax Benefits of Debt?, Journal of Finance, 55-5, 1901-41.

Hamermesh, Daniel S., and John R. Wolfe, 1990, Compensating Wage Differentials and the Duration of Wage loss, Journal of Labor Economics, 8-1, S175-S197.

Harris, Milton, and Bengt Holmstrom, 1982, A Theory of Wage Dynamics, Review of Economic Studies 49, 315-333.

Hirsch, Barry T. and David A. Macpherson, 2003, Union membership and coverage database from the current population survey: Note, Industrial and Labor Relations Review 56, 349-54.

Hotchkiss, Edith S., 1995, Post-bankruptcy Performance and Management Turnover, Journal of Finance, 50, 3-21.

Jacobson, Louis S., Robert J. LaLonde, and Daniel G. Sullivan, 1993, Earnings Losses of Displaced Workers, American Economic Review, 83-4, 685-709.

Jaggia, Priscilla B., and Anjan V. Thakor, 1994, Firm-Specific Human Capital and Optimal Capital Structure, International Economic Review, 35-2, 283-308.

Jiang, Wei, Kai Li, and Wei Wang, 2012, Hedge Funds and Chapter 11, Journal of Finance, 67, 513-60.

Jovanovic, Boyan, 1979, Job Matching and the Theory of Turnover, Journal of Political Economy, 87-5, 972-90.

Lazear, Edward P., 1981, Agency, Earnings Profiles, Productivity, and Hours Restrictions, American Economic Review, 71, 606-620.

Li, Elizabeth H., 1986, Compensating Differentials for Cyclical and Noncyclical Unemployment: The Interaction between Investors' and Employees' Risk Aversion, Journal of Labor Economics, 4-2, 277-300.

LoPucki, Lynn M. and William C. Whitford, 1992, Patterns in the Bankruptcy Reorganization of Large, Publicly Held Companies, Cornell Law Review 78, 597.

Kim, Hyunseob, 2012, Labor Market Size and Capital Structure: Evidence from Large Plant Openings, Working paper, Cornell University.

Kraus, Alan, and Robert H. Litzenberger, 1973, A State-Preference Model of Optimal Financial Leverage, Journal of Finance, 28-4, 911-22.

Maksimovic, Vojislav and Gordon Phillips, 1998, Asset Efficiency and Reallocation Decisions of Bankrupt Firms, Journal of Finance, 63-5, 1495-532. 
Matsa, David A. 2010, Capital Structure as a Strategic Variable: Evidence from Collective Bargaining, Journal of Finance, 49-3, 1197-232.

Molina, Carlos A. 2005, Are Firms Underleveraged? An Examination of the Effect of Leverage on Default Probabilities, Journal of Finance, 60-3, 1427-59.

Neal, Derek, 1995, Industry-Specific Human Capital: Evidence from Displaced Workers, Journal of Labor Economics 13, 653-677.

Ondersma, Chrystin, 2009, Employment Patterns in Relation to Bankruptcy, The American Bankruptcy Law Journal, 83, 237-251.

Opler, Tim C., and Sheridan Titman, 1994, Financial Distress and Corporate Performance, Journal of Finance, 83-5, 1015-40.

Pulvino, Todd C., 1998, Do Asset Fire Sales Exist? An Empirical Investigation of Commercial Aircraft Transactions, Journal of Finance, 53-3, 939-78.

Pulvino, Todd C., 1999, Effects of Bankruptcy Court Protection on Asset Sales, Journal of Financial Economics, 52, 151-86.

Ramey, Valerie A., and Matthew D. Shapiro, 2001, Displaced Capital: A Study of Aerospace Plant Closings, Journal of Political Economy, 109-5, 958-92.

Robinson, Chris, 1989, The Joint Determination of Union Status and Union Wage Effects: Some Tests of Alternative Models, Journal of Political Economy, 97-3, 639-67.

Ruhm, Christopher J., 1991, Are Workers Permanently Scarred by Job Displacements?, American Economic Review, 81-1, 319-24.

Senbet, Lemma W., and Tracy Yue Wang, 2012, Corporate Financial Distress and Bankruptcy: A Survey, Foundations and Trends in Finance Forthcoming.

Shleifer, Andrei, and Robert W. Vishny, 1992, Liquidation Values and Debt Capacity: A Market Equilibrium Approach, Journal of Finance, 47-4, 1343-66.

Titman, Sheridan, 1984, The Effect of Capital Structure on a Firm's Liquidation Decision, Journal of Financial Economics, 13, 137-51.

Topel, Robert H., 1984, Equilibrium Earnings, Turnover, and Unemployment: New Evidence, Journal of Labor Economics 2, 500-522.

Topel, Robert H., 1991, Specific Capital, Mobility, and Wages: Wages Rise with Job Seniority, Journal of Political Economy, 99-1, 145-76.

Wang, Jialan, 2009, The Role of Human Capital in Corporate Bankruptcy, Working Paper, Washington University in St. Louis.

Warner, Jerold B., 1977, Bankruptcy Costs: Some Evidence, Journal of Finance, 32-2, 337-347. 


\section{Table 1}

\section{Summary Statistics on Bankruptcy Events and Firm Characteristics}

This table provides summary statistics on the events of corporate bankruptcy fillings from 1992 to 2008 obtained from Lynn LoPucki. Panel A shows the procedure to select a sample of bankruptcy events used in this paper. We exclude firms in the financial and utilities sectors because leverage ratios in these firms are not directly comparable with those of industrial firms. BRB refers to LEHD-Business Register Bridge, which is used to link the LEHD data to other Census datasets. Panel B (Panel C) breaks down the number of events by period (industry sector). Census Bureau disclosure rules do not allow us to break down in further detail (e.g., by year or 1-digit SIC industry) because then the number of events becomes too small for some years, which may lead to a disclosure risk. Panel D shows summary statistics on characteristics of firms that file for bankruptcy. The statistics are based on values for the latest fiscal year before bankruptcy (usually year $t-1, t-2$, or $t-3$, where "year $t$ " is the year of bankruptcy filings). Panel E presents the dynamics of bankrupt firms' mean characteristics from t-5 to t-1. "Sales" is total sales; "Cash flow" is defined as (net income + depreciation and amortization)/lagged assets; "Book value of assets" is total book value of assets in millions of dollars; "Market value of equity" is market capitalization in millions of dollars; "Book (Market) leverage" is defined as total debt/(total debt + book (market) value of equity); "ROA" is operating income before depreciation and amortizations / lagged assets; "M2B" is defined as (book value of debt + market value of equity)/(book value of debt + book value of equity); "N. emp" is the number of employees in a firm, measured in thousands; "Wage/assets" is total wage from the (Longitudinal Business Database) LBD/book assets; "Wage per worker" is total wage/number of employees in a firm from the LBD. All dollar amounts are CPI-adjusted based on year 2001 constant dollar.

\section{Panel A: Sample Selection Procedure for Bankruptcy Events}

\begin{tabular}{lc}
\hline \hline \multicolumn{1}{c}{ Sample Selection Procedure } & Num. Events \\
\hline All Bankruptcy Cases from LoPucki Database from 1992 to 2008 & 586 \\
Exclude financialand utilities sectors & 503 \\
Matched with Compustat and BRB & 412 \\
Matched with LEHD data & 138 \\
\hline \hline
\end{tabular}

Panel B: Number of Bankruptcy Events by Period

\begin{tabular}{cccc}
\hline \hline Year & All events & $\begin{array}{c}\text { LEHD- } \\
\text { matched }\end{array}$ & Match rate \\
\hline $1992-1997$ & 81 & 11 & 0.14 \\
$1998-2003$ & 265 & 99 & 0.37 \\
$2004-2008$ & 66 & 28 & 0.42 \\
\hline Total & 412 & 138 & 0.33 \\
\hline \hline
\end{tabular}

Panel C: Number of Bankruptcy Events by Sector

\begin{tabular}{lcc}
\hline \hline \multicolumn{1}{c}{ Sector } & $\begin{array}{c}\text { LEHD- } \\
\text { matched }\end{array}$ & Fraction \\
\hline Manufacturing & 59 & 0.43 \\
Non-manufacturing & 79 & 0.57 \\
\hline Total & 138 & 1.00 \\
\hline \hline
\end{tabular}


Panel D: Characteristics of Bankrupt Firms

\begin{tabular}{lcccc}
\hline \hline & \multicolumn{2}{c}{ LEHD-matched bankrupt } & \multicolumn{2}{c}{ All bankrupt firms } \\
\hline Variable & Mean & STD & Mean & STD \\
\hline Sales $(\$ \mathrm{~m})$ & 2,607 & 9,186 & 1,598 & 6,017 \\
Book value of assets $(\$ \mathrm{~m})$ & 1,758 & 5,656 & 1,291 & 3,808 \\
Market value of assets $(\$ \mathrm{~m})$ & 2,345 & 10,741 & 1,609 & 7,104 \\
Market value of equity $(\$ \mathrm{~m})$ & 637 & 5,246 & 363 & 3,303 \\
Book leverage & 0.64 & 0.38 & 0.66 & 0.39 \\
Market leverage & 0.65 & 0.37 & 0.65 & 0.38 \\
ROA & 0.05 & 0.11 & 0.02 & 0.19 \\
M2B & 1.08 & 0.72 & 1.14 & 0.86 \\
N. emp. (000) & 13,762 & 28,226 & 8,310 & 19,700 \\
Wage / Assets & 0.39 & 0.81 & 0.30 & 0.93 \\
Wage per worker (\$) & 35,346 & 19,216 & 42,436 & 33,811 \\
No. firm-level observations & 138 & - & 355 & - \\
\hline \hline
\end{tabular}

Panel E: Evolution of Mean Firm Characteristics before Bankruptcy

\begin{tabular}{lccccc}
\hline \hline Year & $\mathbf{t}-\mathbf{5}$ & $\mathbf{t}-\mathbf{4}$ & $\mathbf{t}-\mathbf{3}$ & $\mathbf{t}-\mathbf{2}$ & $\mathbf{t}-\mathbf{1}$ \\
\hline Sales $(\$ \mathrm{~m})$ & 1,921 & 2,085 & 2,315 & 2,532 & 3,022 \\
Book value of assets $(\$ \mathrm{~m})$ & 1,478 & 1,632 & 1,805 & 1,971 & 2,081 \\
Market value of assets $(\$ \mathrm{~m})$ & 1,652 & 1,920 & 2,106 & 2,390 & 2,754 \\
Market value of equity $(\$ \mathrm{~m})$ & 662 & 861 & 892 & 828 & 781 \\
Book leverage & 0.41 & 0.43 & 0.45 & 0.52 & 0.63 \\
Market leverage & 0.36 & 0.37 & 0.41 & 0.49 & 0.64 \\
ROA & 0.14 & 0.14 & 0.11 & 0.08 & 0.04 \\
M2B & 1.54 & 1.65 & 1.49 & 1.23 & 1.05 \\
N. emp. (000) & 15,728 & 15,351 & 16,160 & 15,772 & 14,344 \\
Wage per worker $(\$)$ & 37,876 & 41,546 & 36,595 & 36,564 & 36,033 \\
No. of firm level observations & 104 & 104 & 104 & 104 & 104 \\
\hline \hline
\end{tabular}


Table 2

\section{Summary Statistics on Employees in Bankrupt Firms}

This table provides summary statistics of the workers who are employed by a bankrupt firm one year prior to the bankruptcy filing. The wage data are from the LEHD-EHF (Employment History Files) and cover the period from 1992 to 2008. We require that the sample workers have at least 6 years of experience and are aged between 22 and 55 in the year before the bankruptcy filing (i.e., year t-1). We adjust wages for inflation using CPI (based on year 2001 constant dollar). The control group is a 1\% random sample of workers from the entire LEHD-EHF data who are not displaced, and satisfies the same requirements for industry (i.e., excluding finance and utilities sectors), tenure, and age as the workers in the bankruptcy sample.

\begin{tabular}{lcccc}
\hline \hline & $(1)$ & $(2)$ & $(3)$ & $(4)$ \\
\hline \multicolumn{1}{c}{ Sample: } & \multicolumn{1}{c}{ Workers in bankrupt firms } & \multicolumn{2}{c}{ Workers in control group } \\
\hline & Mean & STD & Mean & STD \\
\cline { 2 - 5 } Years of education & 13.7 & 2.3 & 13.8 & 2.4 \\
Age & 42.8 & 7.8 & 41.7 & 8.3 \\
Years of experience & 23.1 & 7.8 & 21.9 & 8.2 \\
Wage (t-1) in 2001 dollar & 39,956 & 34,609 & 44,777 & 35,003 \\
\% of females & $44 \%$ & $50 \%$ & $44 \%$ & $50 \%$ \\
\% of workers who stay with & & & & \\
bankrupt firm till t+5 & $55 \%$ & $50 \%$ & - & - \\
Num. of employees & 96,538 & & 136,657 & \\
Num. of firms & 138 & & 3,010 & \\
\hline \hline
\end{tabular}




\section{Table 3}

\section{Mean Wage Trend before and after Bankruptcy}

This table shows the dynamics of mean wages for all the workers employed by firms that file bankruptcy in year $t$. For each of the years surrounding bankruptcy (i.e., from $t-5$ to $t+5$ ), we first calculate the average wage among all the employees present in the company in the particular year (Column 1), and then estimate the percentage wage change relative to the average wage for the base year t-5 (Column 2). For each year, the percentage wage change relative to one year earlier is presented in Column (3).

\begin{tabular}{cccc}
\hline \hline & $\begin{array}{c}\text { (1) Average wage } \\
\text { Event year }\end{array}$ & $\begin{array}{c}\text { (2) Cumulative wage change } \\
\text { relative to } \mathrm{t}-5\end{array}$ & $\begin{array}{c}\text { (3) Wage change relative } \\
\text { to the previous year }\end{array}$ \\
\hline $\mathrm{t}-5$ & 42,419 & - & - \\
$\mathrm{t}-4$ & 48,036 & $13.2 \%$ & $13.2 \%$ \\
$\mathrm{t}-3$ & 44,701 & $5.4 \%$ & $-6.9 \%$ \\
$\mathrm{t}-2$ & 43,686 & $3.0 \%$ & $-2.3 \%$ \\
$\mathrm{t}-1$ & 42,594 & $0.4 \%$ & $-2.5 \%$ \\
$\mathrm{t}$ & 33,577 & $-20.8 \%$ & $-21.2 \%$ \\
$\mathrm{t}+1$ & 31,575 & $-25.6 \%$ & $-6.0 \%$ \\
$\mathrm{t}+2$ & 31,030 & $-26.9 \%$ & $-1.7 \%$ \\
$\mathrm{t}+3$ & 31,643 & $-25.4 \%$ & $2.0 \%$ \\
$\mathrm{t}+4$ & 30,335 & $-28.5 \%$ & $-4.1 \%$ \\
$\mathrm{t}+5$ & 28,765 & $-32.2 \%$ & $-5.2 \%$ \\
\hline \hline
\end{tabular}




\section{Table 4}

\section{Regression Analysis of Wage Losses around Bankruptcy}

This table shows results for the regression analysis of wage losses for workers employed by bankrupt firms one year prior to the bankruptcy filing. The dependent variable is $\log$ (wage in real dollars), where real wage is the wage in 2001 constant dollar. (1) - (3) are based on difference-in-difference regressions with worker and year fixed effects, while (4) further includes (2-digit SIC) industry fixed effects. All of the regressions control for the following worker characteristics: years of experience, years of education $\times$ years of experience, and gender $\times$ years of experience. This table reports the coefficient estimates for the event year indicator variables: $d[t+j]$, where $\mathrm{j}=-4$ to +5 . The regressions use the observations from $\mathrm{t}-6$ to $\mathrm{t}+5$ and the benchmark wage is constructed as the average wage between $\mathrm{t}-6$ and $\mathrm{t}-5$. This is to reduce noise from using one year as benchmark. Detailed definitions of all the variables are reported in Appendix A. Heteroskedasticity robust t-statistics adjusted for within firm clustering are in parentheses. Statistical significance at the $10 \%, 5 \%$, and $1 \%$ levels is indicated by $*$, $* *$, and $* * *$, respectively.

\begin{tabular}{|c|c|c|c|}
\hline & (1) & $(2)$ & (3) \\
\hline Sample: & $\begin{array}{c}\text { Bankruptcy sample } \\
\text { only }\end{array}$ & $\begin{array}{c}\text { Bankruptcy }+ \\
\text { control samples }\end{array}$ & $\begin{array}{c}\text { Bankruptcy }+ \text { control } \\
\text { samples }\end{array}$ \\
\hline Dep. Var.: & Log(wage) & Log(wage) & Log(wage) \\
\hline \multirow[t]{2}{*}{$d[t-4]$} & .058 & .052 & .047 \\
\hline & $(1.97)^{* *}$ & $(2.05)^{* *}$ & $(1.90)^{*}$ \\
\hline \multirow[t]{2}{*}{$d[t-3]$} & .092 & .078 & .067 \\
\hline & $(2.98) * * *$ & $(3.18) * * *$ & $(3.01)^{* * *}$ \\
\hline \multirow[t]{2}{*}{$\mathrm{d}[\mathrm{t}-2]$} & .094 & .080 & .061 \\
\hline & $(1.98)^{* *}$ & $(2.18)^{* *}$ & $(1.80)^{*}$ \\
\hline \multirow[t]{2}{*}{$\mathrm{d}[\mathrm{t}-1]$} & -.030 & -.058 & -.082 \\
\hline & $(-.55)$ & $(-1.60)$ & $(-2.34)^{* *}$ \\
\hline \multirow[t]{2}{*}{$\mathrm{d}[\mathrm{t}]$} & -.146 & -.180 & -.175 \\
\hline & $(-1.44)$ & $(-2.20)^{* *}$ & $(-2.38) * *$ \\
\hline \multirow[t]{2}{*}{$\mathrm{d}[\mathrm{t}+1]$} & -.308 & -.362 & -.327 \\
\hline & $(-2.29)^{* *}$ & $(-3.45)^{* * *}$ & $(-3.60) * * *$ \\
\hline \multirow[t]{2}{*}{$\mathrm{d}[\mathrm{t}+2]$} & -.294 & -.381 & -.295 \\
\hline & $(-2.06)^{* *}$ & $(-3.69)^{* * *}$ & $(-3.28)^{* * *}$ \\
\hline \multirow[t]{2}{*}{$\mathrm{d}[\mathrm{t}+3]$} & -.307 & -.422 & -.318 \\
\hline & $(-1.94)^{*}$ & $(-3.85)^{* * *}$ & $(-3.36)^{* * *}$ \\
\hline \multirow[t]{2}{*}{$\mathrm{d}[\mathrm{t}+4]$} & -.278 & -.442 & -.335 \\
\hline & $(-1.44)$ & $(-3.39) * * *$ & $(-2.85)^{* * *}$ \\
\hline \multirow[t]{2}{*}{$\mathrm{d}[\mathrm{t}+5]$} & -.277 & -.441 & -.329 \\
\hline & $(-1.22)$ & $(-2.96)^{* * *}$ & $(-2.40)^{* *}$ \\
\hline Worker-level controls & Y & Y & Y \\
\hline Year fixed effects & $\mathrm{Y}$ & $\mathrm{Y}$ & Y \\
\hline Employee fixed effects & $\mathrm{Y}$ & $\mathrm{Y}$ & Y \\
\hline Industry (SIC2) fixed effects & $\mathrm{N}$ & $\mathrm{N}$ & $\mathrm{Y}$ \\
\hline No. of worker-year obs. & 806,914 & $2,097,689$ & $2,097,689$ \\
\hline R-squared & $65.49 \%$ & $66.35 \%$ & $69.05 \%$ \\
\hline
\end{tabular}




\section{Table 5}

\section{Wage Loss by Displacement Status and Pre-bankruptcy Union Coverage}

This table presents the estimates of wage losses in bankruptcy, conditional on whether an employee stays with or leave the bankrupt firm (column 1) or industry (column 2) and whether the bankrupt firm is in a highly unionized industry (column 3). "Dummy" is equal to one if an employee leaves his/her current employer that is in distress (column 1), two-digit SIC industry (column 2), or the bankrupt employer is in an above-median union coverage industry (column 3). Median union coverage is based on the t-1 union coverage of the industries in which the workers' employers are. All dollar amounts are CPI-adjusted based on year 2001 constant dollar. Heteroskedasticity robust t-statistics adjusted for within firm clustering are in parentheses. Statistical significance at the $10 \%, 5 \%$, and $1 \%$ levels is indicated by $* * *$, and $* * *$, respectively.

\begin{tabular}{|c|c|c|c|}
\hline & $(1)$ & $(2)$ & $(3)$ \\
\hline $\begin{array}{c}{[\text { Dummy }=1]:} \\
\text { Dep. Var.: }\end{array}$ & $\begin{array}{c}\text { Switch (Firm) } \\
\text { log(wage) }\end{array}$ & $\begin{array}{c}\text { Switch (Industry) } \\
\log (\text { wage })\end{array}$ & $\begin{array}{c}\text { High union coverage } \\
\log (\text { wage })\end{array}$ \\
\hline $\mathrm{d}[\mathrm{t}-4]$ & $\begin{array}{c}.037 \\
(1.36)\end{array}$ & $\begin{array}{c}.044 \\
(1.77)^{*}\end{array}$ & $\begin{array}{c}.070 \\
(1.41)\end{array}$ \\
\hline$d[t-3]$ & $\begin{array}{c}.056 \\
(2.79) * * *\end{array}$ & $\begin{array}{c}.063 \\
(3.15)^{* * *}\end{array}$ & $\begin{array}{c}.109 \\
(2.26)^{* *}\end{array}$ \\
\hline $\mathrm{d}[\mathrm{t}-2]$ & $\begin{array}{c}.047 \\
(1.59)\end{array}$ & $\begin{array}{c}.057 \\
(1.90)^{*}\end{array}$ & $\begin{array}{c}.108 \\
(1.64)\end{array}$ \\
\hline $\mathrm{d}[\mathrm{t}-1]$ & $\begin{array}{c}-.079 \\
(-3.25)^{* * *}\end{array}$ & $\begin{array}{c}-.067 \\
(-2.61)^{* * *}\end{array}$ & $\begin{array}{l}.009 \\
(.10)\end{array}$ \\
\hline $\mathrm{d}[\mathrm{t}]$ & $\begin{array}{c}-.128 \\
(-2.12)^{* *}\end{array}$ & $\begin{array}{c}-.138 \\
(-2.13)^{* *}\end{array}$ & $\begin{array}{c}-.138 \\
(-1.14)\end{array}$ \\
\hline $\mathrm{d}[\mathrm{t}+1]$ & $\begin{array}{c}-.264 \\
(-3.57)^{* * *}\end{array}$ & $\begin{array}{c}-.266 \\
(-3.49)^{* * *}\end{array}$ & $\begin{array}{c}-.233 \\
(-1.46)\end{array}$ \\
\hline $\mathrm{d}[\mathrm{t}+2]$ & $\begin{array}{c}-.184 \\
(-3.36)^{* * *}\end{array}$ & $\begin{array}{c}-.209 \\
(-3.02)^{* * *}\end{array}$ & $\begin{array}{l}-.233 \\
(-1.47)\end{array}$ \\
\hline $\mathrm{d}[\mathrm{t}+3]$ & $\begin{array}{c}-.232 \\
(-4.34)^{* * *}\end{array}$ & $\begin{array}{c}-.239 \\
(-3.57)^{* * *}\end{array}$ & $\begin{array}{l}-.227 \\
(-1.29)\end{array}$ \\
\hline $\mathrm{d}[\mathrm{t}+4]$ & $\begin{array}{c}-.249 \\
(-3.38)^{* * *}\end{array}$ & $\begin{array}{c}-.267 \\
(-2.88)^{* * *}\end{array}$ & $\begin{array}{l}-.216 \\
(-1.16)\end{array}$ \\
\hline $\mathrm{d}[\mathrm{t}+5]$ & $\begin{array}{c}-.355 \\
(-2.32)^{* *}\end{array}$ & $\begin{array}{c}-.315 \\
(-2.46)^{* *}\end{array}$ & $\begin{array}{l}-.169 \\
(-.82)\end{array}$ \\
\hline $\mathrm{d}[\mathrm{t}-4] \times$ Dummy & $\begin{array}{l}.020 \\
(.92)\end{array}$ & $\begin{array}{l}.004 \\
(.18)\end{array}$ & $\begin{array}{l}-.021 \\
(-.42)\end{array}$ \\
\hline $\mathrm{d}[\mathrm{t}-3] \times$ Dummy & $\begin{array}{c}.028 \\
(1.21)\end{array}$ & $\begin{array}{l}.013 \\
(.65)\end{array}$ & $\begin{array}{l}-.040 \\
(-.99)\end{array}$ \\
\hline $\mathrm{d}[\mathrm{t}-2] \mathrm{x}$ Dummy & $\begin{array}{c}.047 \\
(1.72)^{*}\end{array}$ & $\begin{array}{c}.029 \\
(1.24)\end{array}$ & $\begin{array}{l}-.030 \\
(-.58)\end{array}$ \\
\hline $\mathrm{d}[\mathrm{t}-1] \times$ Dummy & $\begin{array}{l}-.002 \\
(-.05)\end{array}$ & $\begin{array}{c}-.051 \\
(-1.15)\end{array}$ & $\begin{array}{c}-.097 \\
(-1.04)\end{array}$ \\
\hline$d[t] x$ Dummy & $\begin{array}{c}-.215 \\
(-4.31)^{* * *}\end{array}$ & $\begin{array}{c}-.263 \\
(-4.65)^{* * *}\end{array}$ & $\begin{array}{l}-.044 \\
(-.50)\end{array}$ \\
\hline
\end{tabular}




\begin{tabular}{lccc}
$\mathrm{d}[\mathrm{t}+1]$ x Dummy & -.299 & -.426 & -.216 \\
$\mathrm{~d}[\mathrm{t}+2]$ x Dummy & $(-4.32)^{* * *}$ & $(-6.28)^{* * *}$ & $(-1.75)^{*}$ \\
& -.420 & -.547 & -.248 \\
$\mathrm{~d}[\mathrm{t}+3]$ x Dummy & $(-5.15)^{* * *}$ & $(-8.09)^{* * *}$ & $(-1.92)^{*}$ \\
& -.395 & -.552 & -.350 \\
$\mathrm{~d}[\mathrm{t}+4]$ x Dummy & $(-3.81)^{* * *}$ & $(-7.10)^{* * *}$ & $(-2.45)^{* *}$ \\
& -.395 & -.533 & -.423 \\
$\mathrm{~d}[\mathrm{t}+5]$ x Dummy & $(-4.73)^{* * *}$ & $(-8.55)^{* * *}$ & $(-3.89)^{* * *}$ \\
& -.212 & -.402 & -.569 \\
Worker-level controls & $(-1.33)$ & $(-4.06)^{* * *}$ & $(-3.91)^{* * *}$ \\
Year fixed effects & $\mathrm{Y}$ & $\mathrm{Y}$ & $\mathrm{Y}$ \\
Individual fixed effects & $\mathrm{Y}$ & $\mathrm{Y}$ & $\mathrm{Y}$ \\
Observations (worker) & $\mathrm{Y}$ & $\mathrm{Y}$ & $\mathrm{Y}$ \\
$\mathrm{R}-$-squared & $2,097,689$ & $2,097,689$ & $2,097,689$ \\
\hline \hline
\end{tabular}




\section{Table 6}

\section{Back-of-the-Envelope Estimate of Present Value of Wage Losses in Bankruptcy}

This table presents a back-of-the-envelope estimate of the present value of wage losses for workers employed by bankrupt firms (relative to market value of the assets of the firm) based on the regression coefficients in Table 4, column 3. Present values are computed using a real discount rate of 5\%. The values in items A, C, E1, and E2 come from Table 1, Panel E. The value in item B is estimated from the regression coefficients in Table 4, Column 3. Specifically, the regression coefficients on the event year indicators in Table 4 represent the change in $\log ($ wage) for the event year relative to the benchmark year, i.e., $\log ($ wage 1$)-\log ($ wage 0$)$, where wage 1 is the wage in the event year and wage 0 is the wage in the benchmark year. Taking exponential of these coefficients and then deducting 1 , we obtain the percent wage change (wage1-wage0)/wage 0 . Multiplying these percent wage changes by wage 0 (which is item $\mathrm{A}, \$ 37,876$ ) gives the dollar amount of wage changes (wage1-wage0) for each year. Summing up the present values of these dollar wage changes from $t$ to $t+5$ gives the value for item $B$ (i.e., present value as of year $\mathrm{t}$ ). All dollar amounts are CPI-adjusted based on year 2001 constant dollar.

\begin{tabular}{|c|c|c|}
\hline Item & Variable & Value \\
\hline A & Average real wage per worker for bankrupt firms in $t-5$ & $\$ 37,876$ \\
\hline B & $\begin{array}{l}\text { Present value of wage losses per worker from } t \text { to } t+5 \text {, } \\
\text { based on regression coefficients in Table } 4 \text {, Column } 3\end{array}$ & $\$ 51,021$ \\
\hline $\mathrm{C}$ & Average number of employees per firm in $\mathrm{t}-5$ & 15,728 \\
\hline $\mathrm{D}=\mathrm{B} \times \mathrm{C}$ & PV of total wage loss for average firm & $\$ 802.46 \mathrm{~m}$ \\
\hline E1 & Average market value of assets in $t-5$ & $\$ 1,652 \mathrm{~m}$ \\
\hline E2 & Average market value of assets in $t-1$ & $\$ 2,754 \mathrm{~m}$ \\
\hline $\mathrm{F} 1=\mathrm{D} / \mathrm{E} 1$ & PV of total wage loss / market value of assets (t-5) & $48.58 \%$ \\
\hline $\mathrm{F} 2=\mathrm{D} / \mathrm{E} 2$ & PV of total wage loss / market value of assets ( $\mathrm{t}-1)$ & $29.14 \%$ \\
\hline
\end{tabular}




\section{Table 7}

\section{An Estimation of Ex-ante Wage Premium}

Using the ex-post wage loss numbers in Table 5, this table estimates the ex-ante expected wage loss (i.e., ex-ante wage premium). The one-year risk-adjusted default probability $\mathrm{q}_{5,1}\left(\mathrm{q}_{10,1}\right)$ is equal to $=1-\left(1-\mathrm{q}_{5}\right)^{1 / 5}\left(1-\left(1-\mathrm{q}_{10}\right)^{1 / 10}\right)$, where $\mathrm{q}_{5}\left(\mathrm{q}_{10}\right)$ is the five-year (ten-year) risk-adjusted default probability provided in Almeida and Philippon (2007) (AP). We use the 5-year probability for 2-year and 5-year tenures (Columns $6 \& 7$ ) and the 10-year one for 10 -year and infinite-year tenures (Columns $9 \& 10)$. Denote the PV of total wage loss for average firm $(802.46$ million from Table 1 Panel E) as wl, and the average market value of sample firms $(\$ 2,754$ million in $\mathrm{t}-1$, from Table 1 Panel E) as A. Assume the risk free rate is $5 \%$ over our sample period. Then Column $6=$ Column $5 /(1+$ risk free rate $) \times \mathrm{wl} / \mathrm{A}$, and Column $10=$ Column $8 /($ Column $8+$ risk free rate $) \times \mathrm{wl} / \mathrm{A}$. Appendix B provides more detailed models and calculations. Tax benefits and wage premiums in the table are the present values of tax benefits and wage premiums, expressed as a percentage of pre-distress firm value.

\begin{tabular}{c|c|c|c|c|c|c|c|c|c}
\hline \hline & $\begin{array}{c}\mathrm{q}_{5}=\text { Five- } \\
\text { year risk } \\
\text { adjusted } \\
\text { Crefault } \\
\text { ratings } \\
\text { probability } \\
\text { from } \\
\text { Table III } \\
\text { in AP }\end{array}$ & $\begin{array}{c}\mathrm{q}_{10}=\text { Ten- } \\
\text { year risk } \\
\text { adjusted } \\
\text { default } \\
\text { probability } \\
\text { from } \\
\text { Table III } \\
\text { in AP }\end{array}$ & $\begin{array}{c}\text { Tax } \\
\text { benefits } \\
\text { of debt } \\
\text { (from } \\
\text { Table } \\
\text { VI in } \\
\text { AP }\end{array}$ & $\begin{array}{c}\mathrm{q}_{5,1}=\text { One } \\
\text { year risk } \\
\text { adjusted } \\
\text { default } \\
\text { probability } \\
\text { based on } \\
\mathrm{q}_{5}\end{array}$ & $\begin{array}{c}\text { Expected } \\
\text { wage } \\
\text { loss } \\
\text { two } \\
\text { period } \\
\text { model) }\end{array}$ & $\begin{array}{c}\text { Expected } \\
\text { wage } \\
\text { loss } \\
\left(\begin{array}{c}5 \text { year } \\
\text { tenure) }\end{array}\right.\end{array}$ & $\begin{array}{c}\mathrm{q}_{10,1}=\text { One } \\
\text { year risk } \\
\text { adjusted } \\
\text { default } \\
\text { probability } \\
\text { based on } \\
\mathrm{q}_{10}\end{array}$ & $\begin{array}{c}\text { Expected } \\
\text { wage } \\
\text { loss } \\
(10 \text { year } \\
\text { tenure) }\end{array}$ & $\begin{array}{c}\text { Expected } \\
\text { wage } \\
\text { loss } \\
\text { (infinite } \\
\text { period } \\
\text { model) }\end{array}$ \\
\hline AAA & $(2)$ & $(3)$ & $(4)$ & $(5)$ & $(6)$ & $(7)$ & $(8)$ & $(9)$ & $(10)$ \\
\hline AA & $0.54 \%$ & $1.65 \%$ & $0.47 \%$ & $0.11 \%$ & $0.03 \%$ & $0.15 \%$ & $0.17 \%$ & $0.42 \%$ & $1.82 \%$ \\
\hline A & $1.65 \%$ & $6.75 \%$ & $2.51 \%$ & $0.33 \%$ & $0.09 \%$ & $0.45 \%$ & $0.70 \%$ & $1.72 \%$ & $6.35 \%$ \\
\hline BBB & $11.39 \%$ & $20.88 \%$ & $5.18 \%$ & $2.39 \%$ & $0.68 \%$ & $3.09 \%$ & $2.31 \%$ & $5.35 \%$ & $14.01 \%$ \\
\hline BB & $21.07 \%$ & $39.16 \%$ & $7.22 \%$ & $4.62 \%$ & $1.31 \%$ & $5.72 \%$ & $4.85 \%$ & $10.09 \%$ & $19.22 \%$ \\
\hline B & $34.90 \%$ & $62.48 \%$ & $8.95 \%$ & $8.23 \%$ & $2.34 \%$ & $9.49 \%$ & $9.34 \%$ & $16.25 \%$ & $22.98 \%$ \\
\hline $\begin{array}{c}\text { BBB } \\
\text { minus }\end{array}$ & $10.85 \%$ & $19.23 \%$ & $4.71 \%$ & $2.28 \%$ & $0.65 \%$ & $2.94 \%$ & $2.15 \%$ & $4.93 \%$ & $12.19 \%$ \\
AAA & $12.72 \%$ & $4.40 \%$ & $1.46 \%$ & $0.41 \%$ & $1.92 \%$ & $1.35 \%$ & $3.25 \%$ & $10.22 \%$ \\
\hline \hline
\end{tabular}


Figure 1

\section{Changes in Wages for Workers Employed by Bankrupt Firms}

This figure presents the real wage changes (in percent), relative to individual-level average wages for five and six years before bankruptcy, based on the regression results in Table 4, Column 3. In the figure, year $t$ is the year of bankruptcy filing.

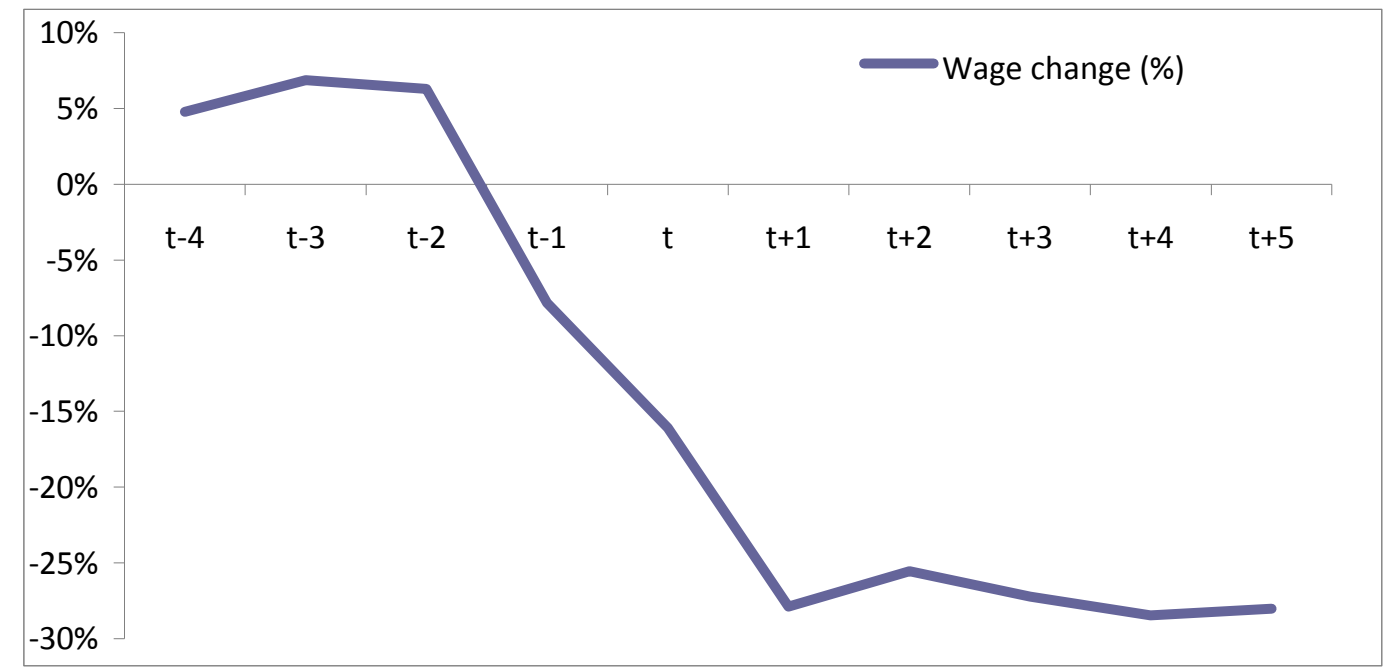




\section{Appendix A: Definition of Variables}

Variable Names

Book value of assets

Market value of assets

Sales

Market value of equity

Market to book

Cash flow

Book (Market) leverage

ROA

N. emp

Wage/assets

Wage per worker

\section{Variable Definitions}

Total book value of assets in \$millions

Market value of equity + book value of debt

Total sales of the company in \$millions

Market value of equity in \$millions

(Book value of debt + market value of equity)/(book value of debt + book value of equity)

(net income + depreciation and amortization)/lagged assets

Total debt/(total debt + book (market) value of equity), where total debt $=$ long term debt + debt in current liabilities

operating income before depreciation and amortizations / lagged book assets

Number of employees in a firm, measured in thousands

Total wage in a firm / book assets

Total wage/number of employees in a firm 


\section{Appendix B: Estimate wage premium due to human costs of bankruptcy}

Because employees experience wage reductions or lose wages when a firm goes into bankruptcy, these employees will demand higher wages ex ante to compensate for such a potential loss. To estimate such wage premiums resulting from bankruptcy, we denote $L$ as the NPV of an employee's expected wage loss, and $W$ as the NPV of the wage that a firm pays when it is not in bankruptcy. $W-L$ is thus the NPV of the expected wage that a firm actually offers to its employees. We first derive the wage premium under a two period model, and then we extend the model to the multi-period case.

B.1 A two period model

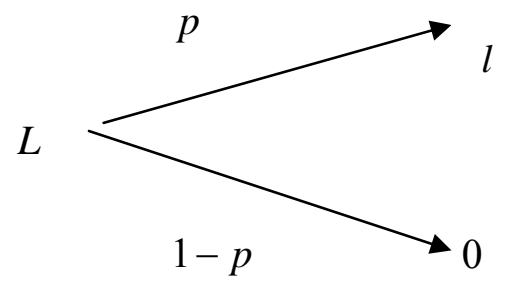

where $l$ is employee's wage loss when a firm defaults; $p$ is the historical probability of default.

Therefore,

$$
L=\frac{p l}{\left(1+r_{D}\right)}
$$

where $r_{D}$ is the appropriate discount rate. Employees are risk averse and bankruptcies are more likely to happen in bad times. Hence, $r_{D}<r_{f}$, the risk free rate. Because we don't know what is the appropriate discount rate $r_{D}$, to estimate $L$, we adopt a risk neutral approach proposed in Almeida and Philippon (2007). Specifically,

$$
L=\frac{q l}{\left(1+r_{f}\right)}
$$


where $q$ is the risk-adjusted probability of bankruptcy, and $r_{f}$ is risk free rate.

Suppose a firm with a default probability $q_{1}$ is offering a competitive market wage to its employees, and the NPV of the wage when the firm is not in default is equal to $W_{1}$. If the firm's risk-adjusted bankruptcy probability increases from $q_{1}$ to $q_{2}$, to attract employees in the competitive labor market, the firm has to offer the same level of expected wage NPV to employees. This implies that

$$
\begin{aligned}
& W_{2}-L_{2}=W_{1}-L_{1} \\
& \Rightarrow
\end{aligned}
$$

Wage premium $=W_{2}-W_{1}=\frac{q_{2} l}{\left(1+r_{f}\right)}-\frac{q_{1} l}{\left(1+r_{f}\right)}=\frac{\left(q_{2}-q_{1}\right)}{\left(1+r_{f}\right)} l$

If we use a risk-free firm (i.e., $q_{1}=0$ ) as the benchmark, then the wage premium of a firm with default risk $q_{2}$ is equal to

Wage premium over a risk free firm $=\frac{q_{2}}{1+r_{f}} l$

This result is intuitive: wage premium is equal to the increase in the expected wage loss resulting from an increased default probability.

B.2 An infinite horizon model

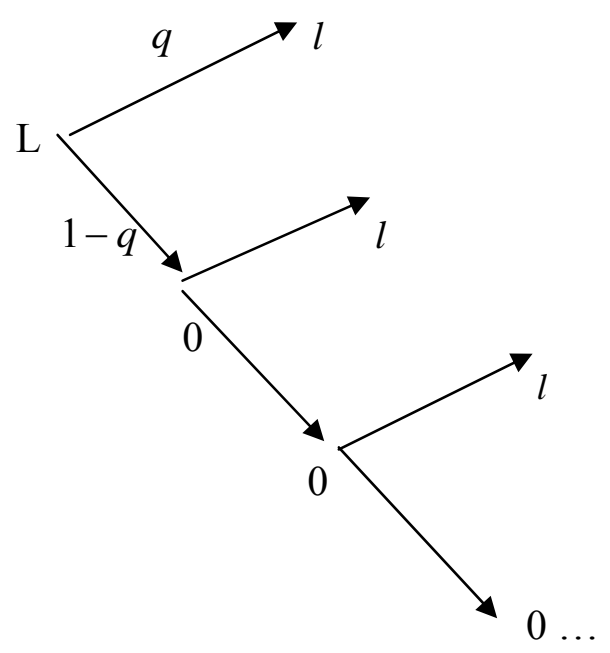


Valuation in this infinite horizon model can be treated as a sequence of two period models.

$$
L=\frac{q l+(1-q) L}{\left(1+r_{f}\right)}=\frac{q l}{q+r_{f}}
$$

Considering a firm whose default probability increases from $q_{1}$ to $q_{2}$, to offer the employees the same expected wage, we need that $W_{1}-L_{1}=W_{2}-L_{2} \Leftrightarrow$ $W_{2}-W_{1}=L_{2}-L_{1}=\frac{q_{2} l}{q_{2}+r_{f}}-\frac{q_{1} l}{q_{1}+r_{f}}=\left(\frac{q_{2}}{q_{2}+r_{f}}-\frac{q_{1}}{q_{1}+r_{f}}\right) l$

For example, if a firm's credit rating changes from AAA to BBB, to compensate workers for the increase in the expected wage loss, wage premium is equal to $W_{B B B}-W_{A A A}=\left(\frac{q_{B B B}}{q_{B B B}+r_{f}}-\frac{q_{A A A}}{q_{A A A}+r_{f}}\right) l$

If we use a risk-free firm, $q=0$, as the benchmark, the wage premium of a firm with a default probability $q$ is equal to Wage premium over a risk free firm $=\frac{q}{q+r_{f}} l$ 


\section{Finite period model}

Here we assume that the employees stay with the company for an average of five years until the firm goes bankrupt. The model can be extended to any finite years.

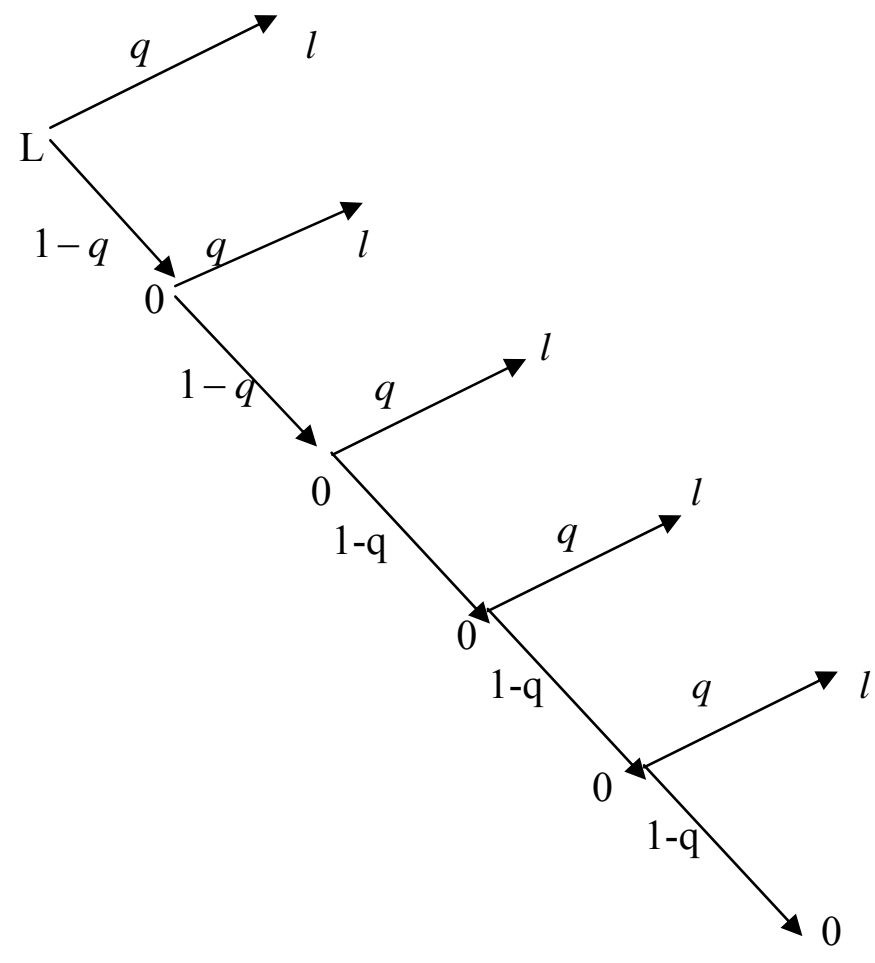

Unconditional risk-adjusted default probability in year $\mathrm{n}=(1-q)^{n-1} q$

Then the NPV of the wage loss in year $\mathrm{n}=\frac{1}{\left(1+r_{f}\right)^{n}}(1-q)^{n-1} q l$

The total NPV of wage loss for employees who work for the firm for $\mathrm{N}$ years is equal to $\sum_{n=1}^{N} \frac{1}{\left(1+r_{f}\right)^{n}}(1-q)^{n-1} q l$ 